\title{
The reputation of the euro and the European Central Bank: Interlinked or disconnected?
}

The Eurozone crisis had a clear impact on trust in the euro and the European Central Bank (ECB). However, drawing on a new study, Stephanie Bergbauer, Nils Hernborg, Jean-François Jamet and Eric Persson explain that there are significant differences in the way citizens place trust in the euro and the ECB. They find that while support for the euro is primarily value based, trust in the ECB depends predominantly on citizens' satisfaction with the EU's overall performance and citizens' outlooks on the economy.

The financial and sovereign debt crisis brought issues of European economic and monetary integration to the fore of political debates. These events were also reflected in citizens' views on the European single currency, the euro, as the most visible outcome of economic and monetary integration in Europe, and the European Central Bank (ECB) as the institution tasked with setting monetary policy for the euro area and maintaining price stability. While large majorities of citizens remained in favour of the euro even at the height of the crisis, trust in the ECB declined substantially, recovering only slowly in recent years (Figure 1). In a recent paper we seek to explain this divergence and identify drivers of support for the euro and trust in the ECB at the individual level.

Figure 1: Net support for the euro and net trust in the ECB in the euro area, 1999-2019

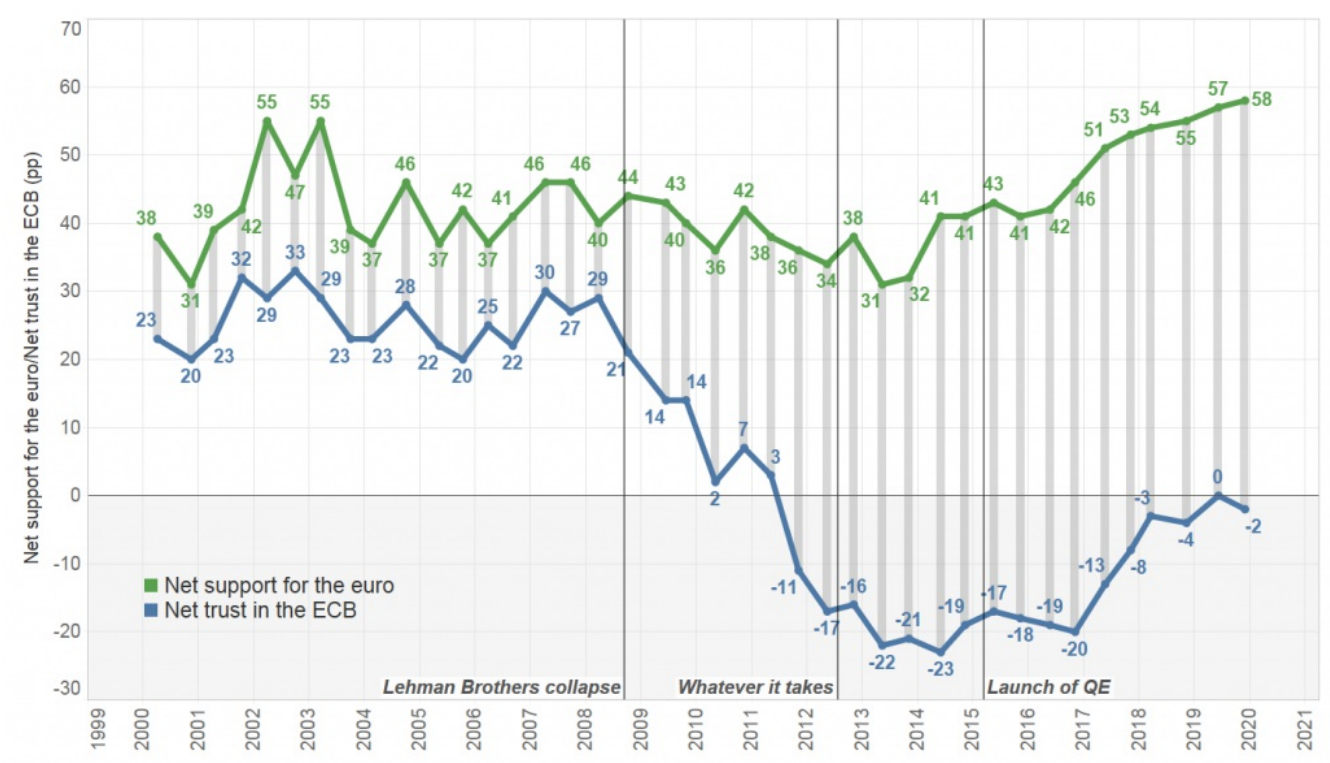

Note: Net support for the euro: \% for single currency minus \% against single currency; Net trust in the ECB= \% 'tend to trust ECB' minus \% of respondents 'tend not to trust'. Source: Eurobarometer surveys, own calculations

The currency and its central bank: mutually dependent on people's trust

Understanding attitudes towards the euro and the ECB is important. People's trust matters. To begin with, a lack confidence in the stability of the currency would make bank runs and inflation fears more likely. Central banks rely on steering public inflation expectations to fulfil their mandate, requiring a high level of trust in the central bank.

In the absence of public support, central banks risk becoming vulnerable to political pressures. Moreover, public support appears even more important in the case of EMU which is seen as a test case for citizens' willingness to transfer core powers of the nation state to the European level. These political bonds were crucial to maintaining cohesion in the crisis when membership in the euro area was framed as creating winners and losers.

Nuances of Euroscepticism: a closer look at supporters and critics of EMU 
Using the microdata from the Eurobarometer surveys we distinguish four types of EMU-supporters and critics. The first group of citizens neither supports the euro nor trusts the ECB - we call this group EMU-sceptics. This group appears the most critical in view of the long-term stability of EMU. Lacking support for the idea of economic and monetary integration per se, these citizens may be open to following anti-euro or generally Eurosceptic voices calling for a break-up of the euro area.

The second group, ECB-sceptics, supports the euro, but does not trust the ECB and thus is the most critical from an ECB perspective. These citizens appear to question the legitimacy of the ECB and its policies, which may make the central bank more vulnerable to political pressures, even if citizens in this group still support the single currency.

The third group, euro-sceptics, does not support the euro, but trusts the ECB. Lacking support for a single European currency, they may be open to anti-euro voices, although continued trust in the ECB may provide a buffer against such arguments. The fourth group, EMU-supporters, supports the euro and trusts the ECB and thus is most conducive to the long-term sustainability of EMU from a theoretical perspective.

\section{The development of citizens' support for EMU since the crisis}

A long-term view on the development of the four groups of EMU-supporters and EMU-sceptics (see Figure 2) shows that prior to the crisis, a relative majority of euro area citizens were EMU-supporters (dark blue line). This group shrinks from the onset of the financial and economic crisis in 2008/2009 and recovers to pre-crisis levels only in 2017/2018. In parallel, the group supporting neither the euro nor the ECB also grows (red line).

With the crisis, some citizens lost confidence in the ECB, but did not necessarily turn against the single currency, as evidenced by the growing number of those still supporting the euro, but lacking trust in the ECB (yellow line). The group of citizens supporting the ECB but not the euro (grey line) is negligibly small across the euro area and over time. Interestingly the share of people without a view on either the euro or ECB (light blue line) decreased over the entire period, suggesting increased interest in matters related to EMU.

Figure 2: Levels and development of EMU support in the euro area 1999-2019

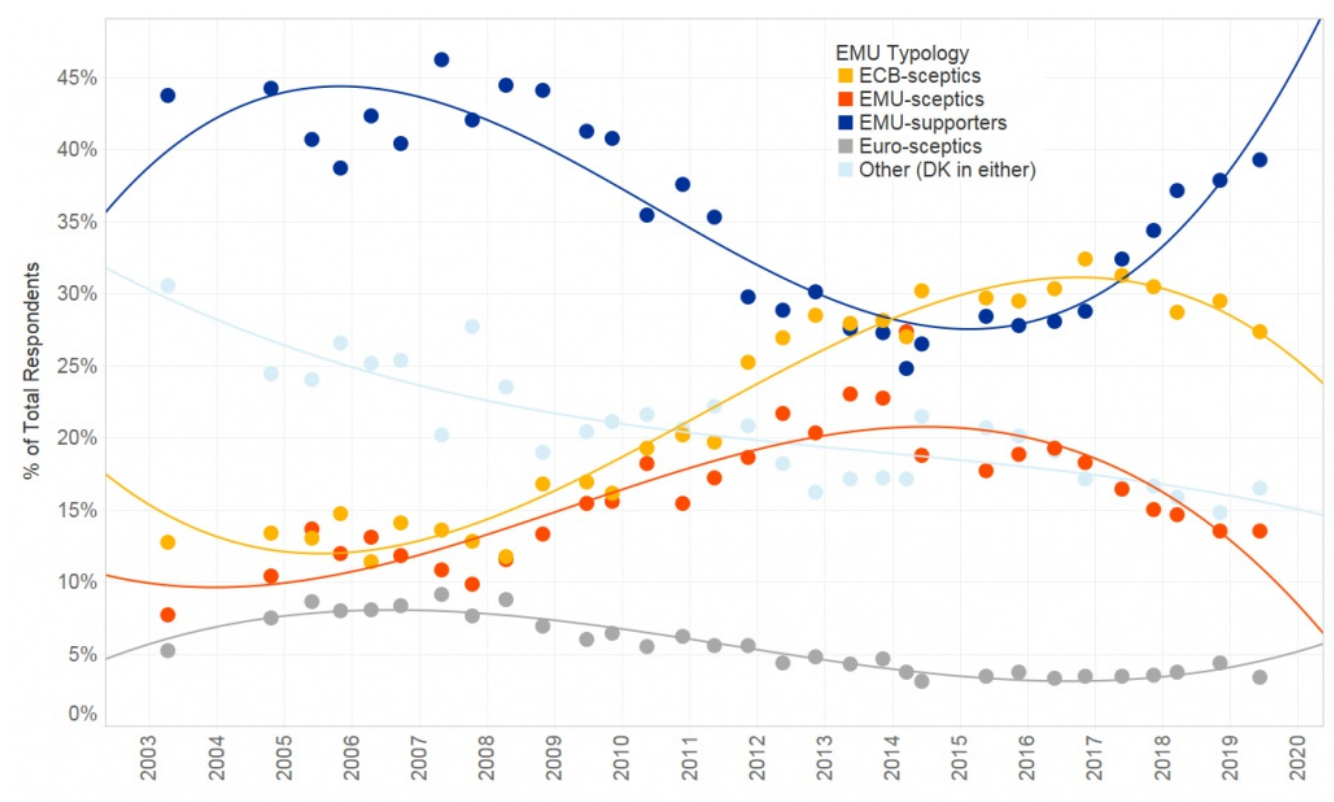

Source: Eurobarometer surveys, own calculations

National publics' views on EMU: a reflection of different experiences of the crisis 
Zooming in on the Member State level, a first group has kept a majority of EMU-supporters since euro adoption, including during the crisis. This group comprises mainly north-western European countries and some of the more recent euro area member states (Austria, Belgium, Estonia, Finland, Latvia, Lithuania, Luxembourg, Malta, Netherlands, Slovakia). In a second group (Cyprus, Greece, Ireland, Italy, Portugal, Slovenia, Spain), public attitudes towards EMU turned distinctly negative in the crisis. A third group consists of the large core economies France and Germany which both have distinct attitudinal patterns towards EMU.

How can we explain the country-specific patterns? One general rationale may be differences in countries' experience of the economic and financial crisis and public perceptions among national publics of the ECB and its role in the crisis. The first group of countries weathered the crisis relatively well, in stark contrast to the second group which includes countries that had to enter into macroeconomic adjustment programmes or, like Slovenia, experienced bank rescues involving a bail-in of junior bond holders. In several of these countries, the ECB was heavily criticised for its participation in the troika, austerity measures under the adjustment programmes and its role in decisions regarding bank rescues.

France has had a historically muted but stable support for the EMU and trust in the ECB. In Germany, ECBsceptics have become more numerous since the onset of the financial crisis in 2007/2008, mirroring the German public debate in the aftermath of the crisis that tends to highlight the adverse effects of ECB policies, in particular on savers and pensioners.

\section{Figure 3: Levels and development of EMU-support in euro area member states, 1999-2018}

Levels and development of EMU-support by Member State (1999-2018)

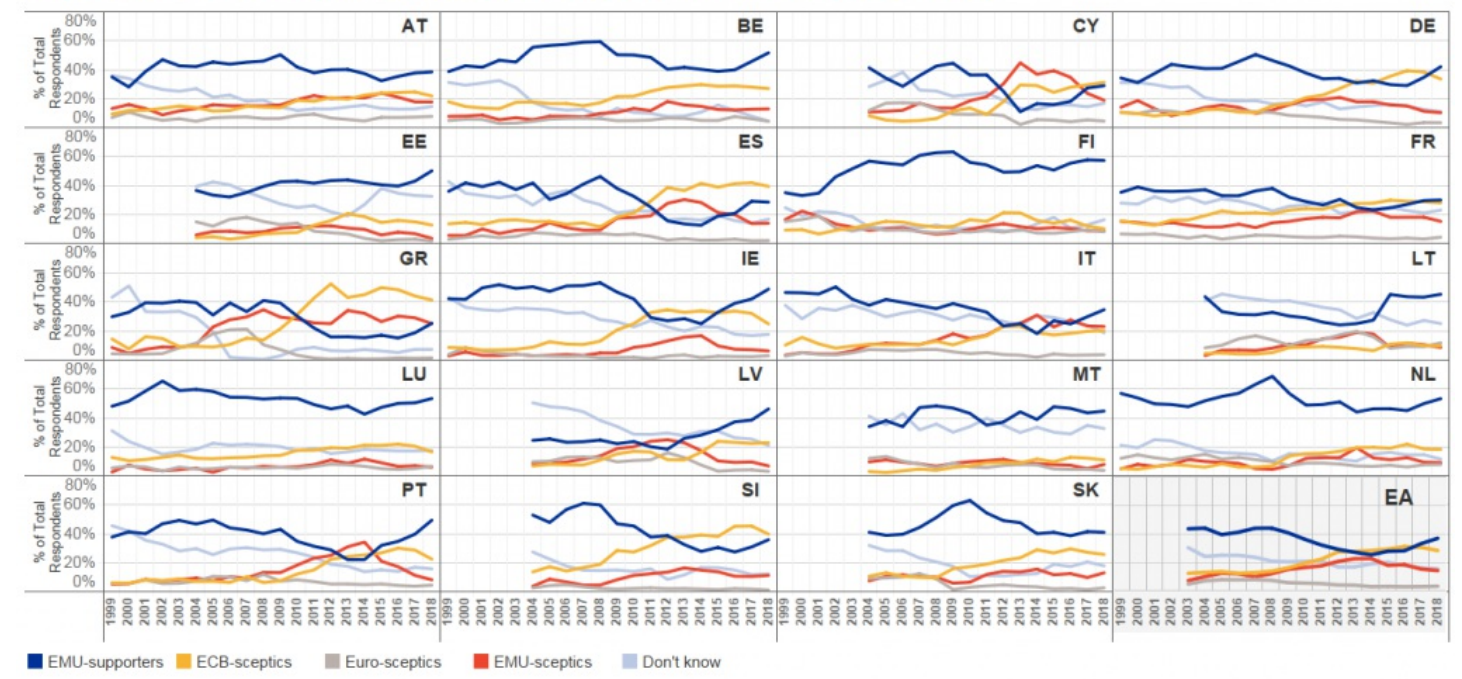

Source: Eurobarometer

\section{Understanding people's motivations: values vs perceived performance}

Going back to the initial puzzle set out in the introduction, we find that support for the euro is primarily value based: it relates to feelings of European identity and support for the idea of European integration. Trust in the ECB, in contrast, depends predominantly on citizens' satisfaction with the EU's overall performance and citizens' outlooks on the economy. This suggests that trust in the ECB may be slow to recover for as long as the memory of the crisis continues to impact citizens' assessment of the EU's performance.

We also find that assessments of specific EU crisis measures affect both dimensions of EMU: in particular, the EU's perceived failure to protect citizens and achieve fair burden sharing in the crisis affects support for the euro, suggesting that the single currency is also associated with values of fairness and protection which many citizens saw as lacking in the EU's handling of the crisis. In contrast, the comparatively stronger effect of the EU's failure to hold the financial sector to account on ECB trust may indicate concerns about the ECB's perceived closeness to the financial sector who many view as the main culprits of the financial crisis. 
Overall, our findings suggest that value-based support has been critical during the crisis in ensuring continued public support for EMU despite perceptions of underperformance. More broadly, they reinforce the case that economic integration is more sustainable if it is based on a sense of stability, fairness and togetherness.

For more information, see the authors' accompanying study in the Journal of European Public Policy

Please read our comments policy before commenting.

Note: This article gives the views of the authors, not the position of EUROPP - European Politics and Policy or the London School of Economics. The views expressed are those of the authors, they do not necessarily reflect those of the European Central Bank (ECB) and should not be reported as such. Featured image credit: European Central Bank (CC BY-NC-ND 2.0)

\section{About the authors}

Stephanie Bergbauer - European Central Bank

Stephanie Bergbauer is an Economist at the European Central Bank.

Nils Hernborg - European Central Bank

Nils Hernborg is a Research Analyst at the European Central Bank.

Jean-François Jamet - European Central Bank

Jean-François Jamet is Counsellor to the Executive Board at the European Central Bank.

Eric Persson - European Central Bank

Eric Persson is a Senior Research Analyst at the European Central Bank. 